\title{
EFFECTS OF 99mTc ON THE ELECTROCHEMICAL PROPERTIES OF THIAMAZOLE IN VITRO
}

\author{
Safija Herenda ${ }^{1 *}$, Anera Kazlagić ${ }^{1}$, Edhem Hasković$^{2}$, Jelena Šćepanović ${ }^{3}$, Jasmina Marušić ${ }^{4}$ \\ ${ }^{1}$ Department of Chemistry, Faculty of Science, University of Sarajevo, Zmaja od Bosne 33-35, \\ 71000 Sarajevo, Bosnia and Herzegovina \\ ${ }^{2}$ Department of Biology, Faculty of Science, University of Sarajevo, Zmaja od Bosne 33-35, \\ 71000 Sarajevo, Bosnia and Herzegovina \\ ${ }^{3}$ Faculty of Metallurgy and Technology, University of Montenegro, Džordža Vašingtona bb, \\ Podgorica, Montenegro \\ ${ }^{4}$ University "Vitez", Vitez, Bosnia and Herzegovina \\ islamovic.safija@gmail.com
}

Thiamazole inhibits the synthesis of thyroid hormones and does not inactivate the existing thyroxine and triiodothyronine circulating in the blood. In this paper, the electrochemical behavior of thiamazole was monitored by cyclic voltammetry on a glassy carbon electrode in the presence and absence of sodium pertechnetate $\left({ }^{99 \mathrm{~m}} \mathrm{Tc}\right)$. The influence of different thiamazole concentrations in the presence or absence of radiopharmaceutical ${ }^{99 \mathrm{~m}} \mathrm{Tc}$, the effect of the number of scan cycles, and the effect of ${ }^{99 \mathrm{~m}} \mathrm{Tc}$ activity on the appearance of cyclic voltammograms were examined. The results showed an observed increase in the reduction peak current with an increase in thiamazole concentration. It was found that the concentration of the tested drug had a significant effect on its redox characteristics. The results obtained with the application of different sodium pertechnetate concentrations showed the inhibitory effects of the radiopharmaceutical on the drug in the treatment of thyroid disease.

Keywords: drug; radiopharmaceutical; kinetics; cyclic voltammetry

\section{ВЛИЈАНИЕ НА ${ }^{99 \mathrm{~m}}$ Тс ВРЗ ЕЛЕКТРОХЕМИСКИТЕ СВОЈСТВА НА ТИАМАЗОЛ IN VITRO}

Тиамазол е инхибитор на синтезата на тироидните хормони кој не ги деактивира присутните хормони тироксин и тријодотиронин кои циркулираат во крвта. Во овој труд се испитувани електрохемиските својства на тиамазол со примена на циклична волтаметрија на работна електрода од стаклест јаглерод во присуство и отсуство на натриум пертехнат $\left({ }^{99 \mathrm{~m}} \mathrm{Tc}\right)$. Испитувани беа влијанието на концентрацијата на тиамазол во присуство и отсуство на радиофармацевтскиот препарат ${ }^{99 \mathrm{~m}} \mathrm{Tc}$, влијанието на бројот на волтаметриски циклуси, како и влијанието на ${ }^{99 \mathrm{~m}} \mathrm{Tc}$ врз својствата на цикличните волтамограми. Резултатите покажаа зголемување на волтаметрискиот пик на редукција со зголемување на концентрацијата на тиамазол. Забележано е дека концентрацијата на испитуваниот аналит има значително влијание врз карактеристиките на волтаметрискиот одговор. Резултатите добиени при различни концентрации на натриум пертехнат покажаа инхибирачки ефект на радиофармацевтскиот препарат врз медикаментот што се употребува во третман на тироидни заболувања.

Клучни зборови: медикаменти; радиофармацевтски формулации; кинетика; циклична волтаметрија 


\section{INTRODUCTION}

The thyroid gland is one of the largest endocrine glands in the human body. Thyroid hormones are involved in the regulation of both the basal metabolic state and the oxidative state. High levels of thyroid hormones stimulate the formation of free radicals in mitochondria, affecting oxygen metabolism [1]. Numerous cellular enzymatic processes in the cytosol, the endoplasmic reticulum, peroxisomes, and the inner and the outer mitochondrial membranes generate reactive oxygen species (ROS) [2]. ROS play a significant role in physiological processes, which can lead to oxidative damage of various molecules [3] and is a condition that occurs as a consequence of the disproportionate effect of thyroid hormones. The most prevalent cause of hyperthyroidism is autoimmune thyroid gland disease and TSH-TSH receptor (TSH-thyroid stimulating hormone) disease [4]. The excess thyroid hormone in the blood leads to tissue destruction. The medicine most commonly used for the treatment of hyperthyroidism is thiamazole [5]. To diagnose the disease and to determine the condition of the thyroid gland, the vast majority of people who are prescribed these drugs are subjected to scintigraphy, a method where radiopharmaceuticals are administered intravenously [6-7].

Scintigraphy allows the localization of radiopharmaceutical collection sites, and information on the state of the thyroid gland is obtained with the help of $\gamma$-rays [8-9]. The use of ${ }^{131}$ I-iodide for thyroid scintigraphy in nuclear medicine was abolished many years ago due to high dosimetry and unsatisfactory image quality. Its use is limited to extremely low doses (below 30 $\mu \mathrm{Ci}$ ) by some laboratories that insist on obtaining values using this radiograph or high customized doses in capsules for differentiating thyroid cancer and for hyperthyroid therapy. The currently selected radiopharmaceuticals are ${ }^{123}$ I-iodide and ${ }^{99 \mathrm{~m}} \mathrm{Tc}$-pertechnetate.

The radiopharmaceutical investigated in this work was ${ }^{99 \mathrm{~m}} \mathrm{Tc}$ in the form of a sodium pertechnetate solution, and the tests were performed in vitro. The redox properties of ${ }^{99 \mathrm{~m}} \mathrm{Tc}$ can be monitored using an electrochemical method because ${ }^{99 \mathrm{~m}} \mathrm{Tc}$ has stable oxidation states in aqueous solution [10]. ${ }^{99 \mathrm{~m}} \mathrm{Tc}-$ pertechnetate was selected because it is easily accessible and inexpensive. Also, the maximum intravenous ${ }^{99 \mathrm{~m}} \mathrm{Tc}$ application occurs for 10 to 20 minutes, as opposed to ${ }^{131}$ I-iodide, which requires a 24 -hour measurement [11]. Cyclic voltammetry is now used as a technique for studying the redox potential of different types of drugs. By using this technique, it is also possible to establish an irreversible controlled diffusion-reaction by monitoring the effects of $\mathrm{pH}$, scan rate and concentration [12].

Electrochemical techniques such as cyclic voltammetry offer high sensitivity, precision, low cost and accuracy [13]. In previous research, electrochemical methods were used to determine the kinetic parameters and behavior of various drugs in in vitro conditions [14-18]. Voltammetric determination of thiamazole based on its electrochemical oxidation at a glassy carbon (GC) electrode is described in the paper by $\mathrm{Xi}$ [19].

\section{EXPERIMENTAL}

Materials: ${ }^{99 \mathrm{~m}} \mathrm{Tc}$ labeled sodium $\left(t_{1 / 2}=6.01\right.$ $\mathrm{h}, A_{0}=2 \mathrm{mCi}$, commercial generator, Sarajevo General Hospital), $\mathrm{KH}_{2} \mathrm{PO}_{4}$ and $\mathrm{Na}_{2} \mathrm{HPO}_{4}$ (Fisher Chemical, Vienna, Austria); thiamazole (Favistan, Bosnalijek, Sarajevo, BiH). All other compounds used in this study were commercially available as reagents with the highest purity.

Method: The instrument used for the measurements was PAR 263A potentiostat/galvanostat (Princeton Applied Research, Oak Ridge. TN, USA), using a classical three-electrode system, where the GC electrode is used as the working electrode, the reference electrode is a saturated $\mathrm{Ag} / \mathrm{AgCl}$ electrode, while a Pt-electrode is used as the counter electrode. Cyclic voltammetry was used to determine the effect of different thiamazole concentrations and their redox characteristics in a default potential range of -1.5 to $0.7 \mathrm{~V}$ with a scanning speed of $50 \mathrm{mV} / \mathrm{s}$. The studies were conducted in the absence and presence of ${ }^{99 \mathrm{~m}} \mathrm{Tc}$ in a phosphate buffer solution $(\mathrm{pH}=7)$ by measuring the values of peak current for thiamazole in the area of reduction at a potential of $-0.70 \mathrm{~V}$, into the voltammetric cell, through which pure nitrogen (oxygen-free) stream was passed for $10 \mathrm{~min}$ before recording the voltammogram.

\section{RESULTS}

Figure 1 shows the voltammogram of the GC electrode in phosphate buffer, and, as shown in the figure, no interfering peaks were observed in the blank within the studied potential range. In relation to this voltammogram, we added different drug concentrations to the reaction cell. Due to the strict relation between the characteristics of the electrodeposited film and electrode response, 
electrodeposition parameters strongly affect the sensitivity of the modified electrodes.

From cyclic voltammograms, the values of current peaks at different concentrations $([$ thiamazole $]=0.0414,0.0954,0.2230$, and $0.4517 \mathrm{mM}$ ) were measured, as seen in Figure 2. As we know, ideal cyclic voltammograms have symmetric oxidation and reduction peaks of equal heights with both peak potentials at the formal potential of the surface redox reaction [20-22]. Figure 2 shows that the peaks were not symmetrical, since charge transport through the thin film of thiamazole at the electrode depends on the possible physical diffusion of the thiamazole or on the electron self-exchange reactions between drug redox centers. As the thiamazole film increases at the electrode, so does the current rise.
For films that show diffusion-controlled cyclic voltammograms, the integral under the peak is not proportional to the surface concentration of electroactive centers in the film [22]. Oxidation of sulfhydryl groups in the molecule has the following mechanism [23]:

$$
\begin{gathered}
\mathrm{RSH} \longrightarrow \mathrm{RS}^{-}+\mathrm{H}^{+}+\mathrm{e}^{-}\left(\mathrm{RSH}_{\text {is }} \longrightarrow \text { thiamazole }\right) \\
2 \mathrm{RS}^{-} \longrightarrow \mathrm{RSSR}
\end{gathered}
$$

The direct electrooxidation of the thiol moiety (SH) is generally hampered by large anodic overpotential and, consequently, low peak currents at bare solid electrodes. The electrochemical oxidation of thiols can be enhanced remarkably by introducing various electron mediators, such as pertechnate, into the surface layer of the modified electrodes [24].

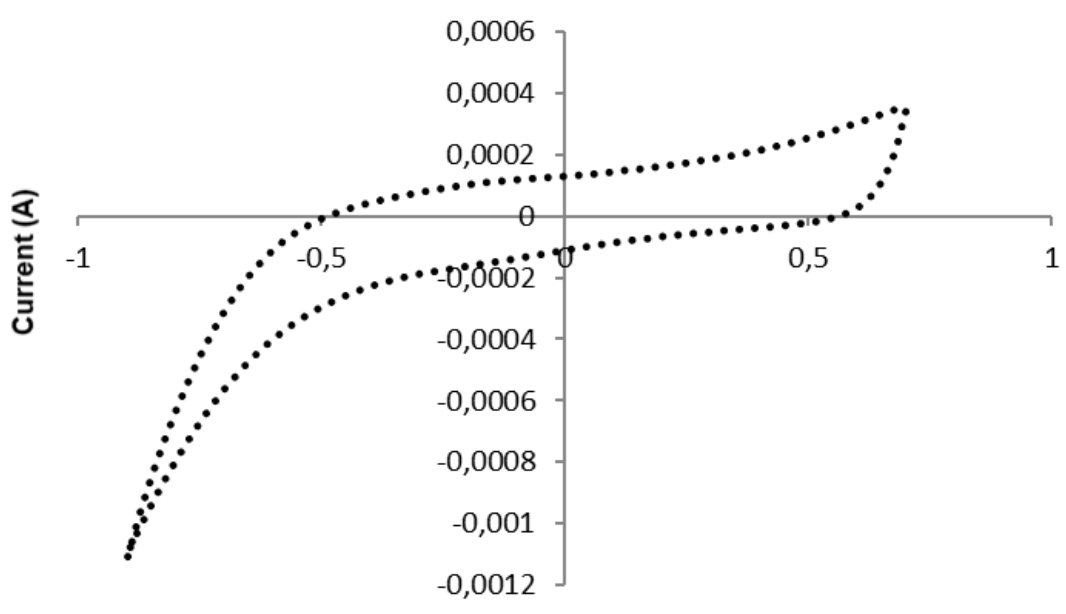

Potential vs $\mathrm{Ag} / \mathrm{AgCl}(\mathrm{V})$

Fig. 1. Cyclic voltammogram of GC electrode in a phosphate buffer

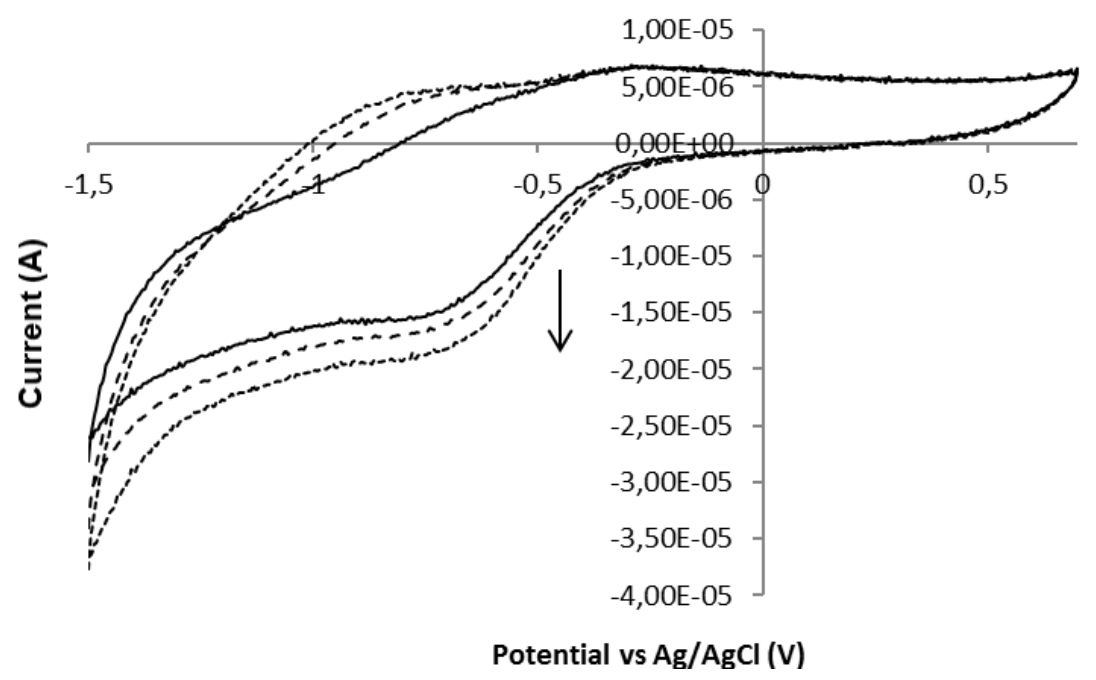

Fig. 2. Cyclic voltammograms for a different concentrations thiamazole: $0.0415 \mathrm{mM}$ (- line); $0.0954 \mathrm{mM}$ (---- line); $0.2230 \mathrm{mM},(\ldots . .$. line $)$ 
In the area of reduction at a potential of $-0.700 \mathrm{~V}$ an increase in the current peak was observed with increasing drug concentration in the solution.

When the data is presented graphically, a curve is obtained showing a linear increase of current with increasing concentration, as shown in Figure 3. The catalytic effect is attributed to the appearance of the SH-group at the electrode surface. These groups have a catalytic effect on electron transfer mechanisms involving proton transfer. Linearity occurs in the interval of thiamazole concentration of 0.0414 to $0.4517 \mathrm{mM}$ and the current range of 9.85 to $14.2 \mu \mathrm{A}$. The electrochemical method obtained a peak current that was linearly proportional to the methimazole concentration in the range of $7.0-130 \mu \mathrm{M}$, as described in the paper by author Jalali et al. [25]. To determine the reaction rate constants, the values of the current as a function of different concentrations of thiamazole, without and with the addition of the ${ }^{99 \mathrm{~m}} \mathrm{Tc}$ solution, are presented graphically in Figure 3.

In the same figure, it can be observed that the currents were lower when ${ }^{99 \mathrm{~m}} \mathrm{Tc}$ was present in the solution, which means that, in this case, ${ }^{99 \mathrm{~m}} \mathrm{Tc}$ shows inhibiting effects on the drug. Thiamazole forms a complex with ${ }^{99 \mathrm{~m}} \mathrm{Tc}$, which usually involves reducing pertechnetate chemically to some lower oxidation state, often Tc(IV), and therefore, currents have a lower value. Such substitutionally inert radiolanthanide complexes are essential for radioisotope therapy because in vivo dissociation of the radiolanthanide from the chelate invariably results in bone and liver uptake [26].

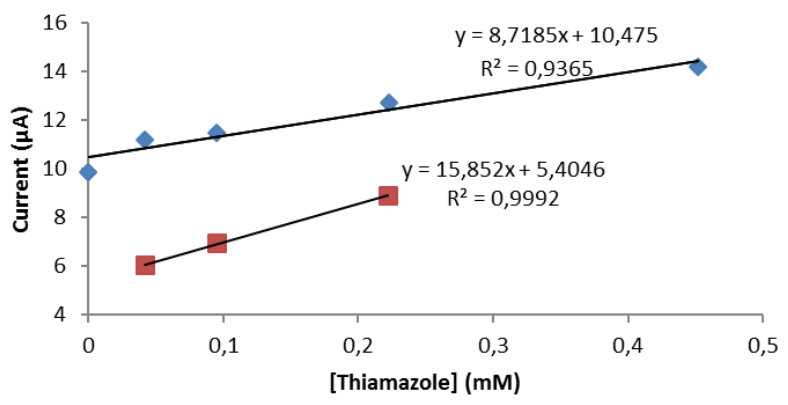

Fig. 3. Current as a function of drug thiamazole concentration, with and without the addition of ${ }^{99 \mathrm{~m}} \mathrm{Tc}$ solution: $(\square)$ with ${ }^{99 \mathrm{~m}} \mathrm{Tc} ;(\diamond)$ without ${ }^{99 \mathrm{~m}} \mathrm{Tc}$

To test whether the drug layer on the surface of the GC electrode was correctly applied, 30 scan cycles of the GC/thiamazole electrode in phosphate buffer were recorded at a scan rate of $50 \mathrm{mV} \mathrm{s}^{-1}$. The recording showed no deviations in the appearance of the curve for every cycle, as can be seen in Figure 4, where the values of the currents in the anode oxidation field are presented at a potential of $0.5255 \mathrm{~V}$.

Since the current is directly proportional to the thickness of the surface film, the deviation of the curve toward larger or smaller values with the increase in the number of cycles indicates an uneven distribution of the drug on the surface of the electrode. In Figure 4, it can be seen that, by the diffusion process, the thiamazole layer is distributed evenly across the surface of the GC electrode. Combining the fact that identical numbers of protons and electrons are involved in the electrode process, we conclude that the electrochemical reaction of thiamazole at the GC electrode might be realized through the oxidation of sulfhydryl groups in the molecule.

An increase in $\Delta E_{\mathrm{p}}$ occurred with an increase in scan rate and the number of cycles for the thiamazole/electrode electroactive film.

When the ideal thin layer results from $\Delta E_{\mathrm{p}}$, the scan speed and the number of cycles can be used to estimate the electron transfer rate constant. In nonideal voltammetric films of some redox drugs, constant separation peaks are observed at low scan rates [27].

To test the effect of the ${ }^{99 \mathrm{~m}} \mathrm{Tc}$ solution on the thiamazole drug, a ${ }^{99 \mathrm{~m}} \mathrm{Tc}$ solution was added at different time intervals. The initial activity of ${ }^{99 \mathrm{~m}} \mathrm{Tc}$ was $2 \mathrm{mCi}$. As time elapsed, a decrease in reduction peaks was observed. The radionuclide activity decreased with time, which can be seen in the data in Table 1 . The activity was calculated based on the formula of the decay law: the half-life of ${ }^{99 \mathrm{~m}} \mathrm{Tc}$ is 6 hours, so its activity decreased with time.

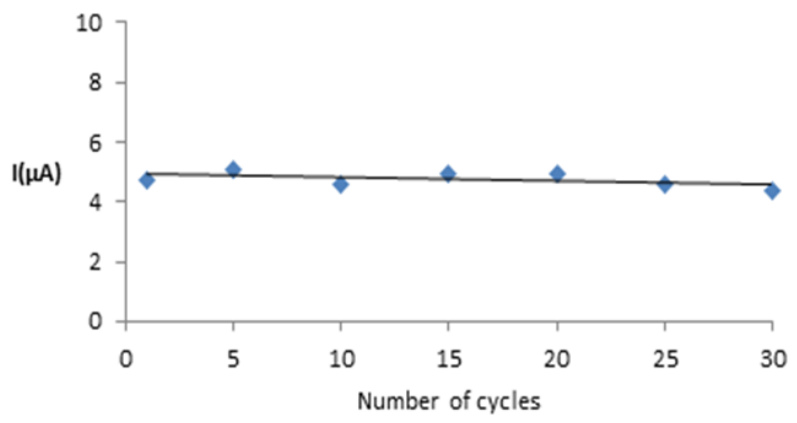

Fig. 4. Dependence of oxidation peak on the number of cycles on the GC/thiamazole electrode in phosphate buffer

Table 1

Change in radionuclide activity with time

\begin{tabular}{cc}
\hline \hline$t / \mathrm{h}$ & $A / \mathrm{mCi}$ \\
\hline 0 & 2.00 \\
3.00 & 1.41 \\
4.75 & 1.16 \\
\hline \hline
\end{tabular}


In Figure 5, three voltammograms of thiamazole in the presence of ${ }^{99 \mathrm{~m}} \mathrm{Tc}$ are shown, where recordings were performed in the potential range of $-1.5 \mathrm{~V}$ to $0.7 \mathrm{~V}$ at a constant scan rate of $50 \mathrm{mV} / \mathrm{s}$. The concentration of thiamazole was constant at $0.222 \mathrm{mM}$. As ${ }^{99 \mathrm{~m}} \mathrm{Tc}$ gradually decays with time, the reduction in the reduction peak is also proportional, which is in accordance with the law of radioactive decay. Figure 6 illustrates the voltammograms of thiamazole in the presence of ${ }^{99 \mathrm{~m}} \mathrm{Tc}$, recorded under the same conditions as in the previous experiments, with the drug concentration being $0.0414 \mathrm{mM}$. It was confirmed that, apart from the drug concentration, the decrease in ${ }^{99 \mathrm{~m}} \mathrm{Tc}$ decreased the reduction peak in the area of reduction.

The order of redox potential of thiamazole controls the thermodynamic values of the reaction between each intermediate state of the components in the chain. However, electron transfer of nonspecific reactions between different drug components, whose thermodynamic values may be much higher than those of specific reactions, can also be achieved. The study of electron transfer from the surface of the electrode and proteins, has been the subject of research for the last 20 years. Research on the three-dimensional structure of different redox proteins and drugs reveals the different effects of the mutation of certain amino acids on the electron transfer rate [28].
Using cyclic voltammetry, we had to consider the cleanliness of the electrode surface and as little denaturation of thiamazole as possible for better electron transfer. The electron transfer in this case depended on the physical diffusion of thiamazole. For films showing diffusion control in cyclic voltammograms, the integral below the peak is not proportional to the surface concentration of the electroactive centers in the film since only some of the drug is being electrolyzed. In Figures 5 and 6 , we can see that the change in potential and the decrease in activity depended on the physicochemical properties of thiamazole as well as on the ability of the drug to reach a certain molar concentration in lipid cells. Two major factors are responsible for the formation of the molar concentration in lipid cells: namely, the drug partition coefficient and the lowest molar concentration of the drug, which must be present in the extracellular fluid. At the concentrations tested, thiamazole changes its potential by passing through biological membranes by diffusion and reaching cells where it exhibits its pharmacological action. The diffusion rate of thiamazole molecules depends on the concentration gradient, as shown in Figures 5 and 6. Thiamazole uptake rate increased with the higher drug concentration of $0.222 \mathrm{mM}$. Depending on the time of application of ${ }^{99 \mathrm{~m}} \mathrm{Tc}$, a thiamazole ${ }^{99 \mathrm{~m}} \mathrm{Tc}$ complex is created that exhibits inhibitory properties and, therefore, lower current values.

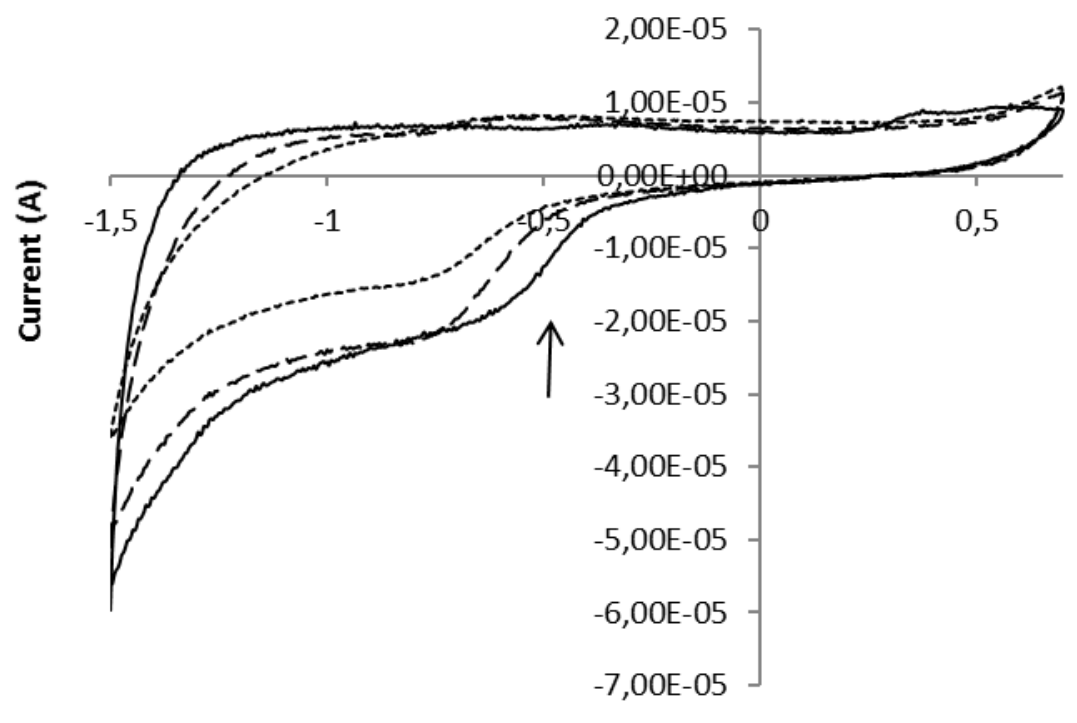

Potential vs $\mathrm{Ag} / \mathrm{AgCl}(\mathrm{V})$

Fig. 5. Cyclic voltammograms for a thiamazole concentration of $0.222 \mathrm{mM}$, before and after the indicated time as follows: initial recording (- line); recording after 3 hours (----line); recording after 4 hours and 45 minutes (.....line) 


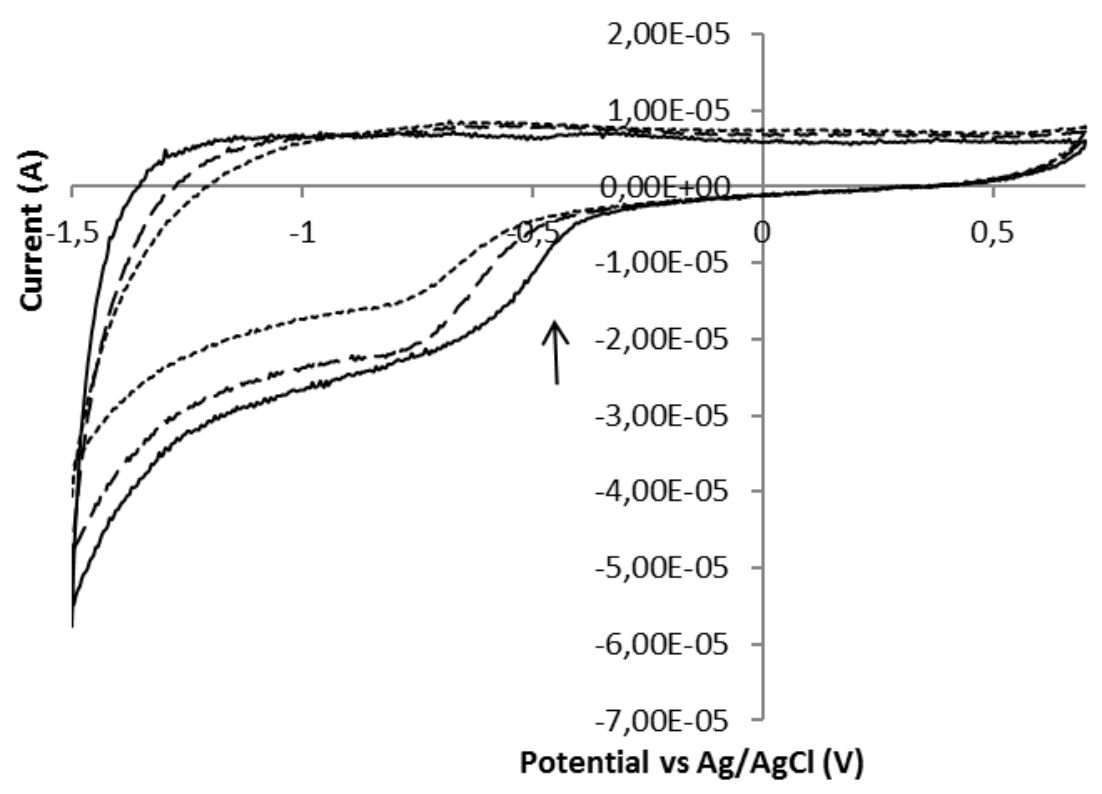

Fig. 6. Cyclic voltammograms for thiamazole at a constant concentration of $0.0414 \mathrm{mM}$, before and after the indicated time as follows: initial recording ( - line); recording after 3 hours (----line); recording after 4 hours and 45 minutes (.....line)

\section{DISCUSSION}

The determination of thiamazole is of great importance in clinical chemistry and pharmaceutical formulation analysis. Numerous analytical techniques have been described for the determination of thiamazole [19]. The redox properties of drugs can give insights into their metabolic fate, their in vivo redox processes, or their pharmacological activity [29]. Transition-metal complexes containing radioactive isotopes have found widespread use as radiopharmaceuticals in diagnostic nuclear medicine. Thin-layer electrochemical techniques such as cyclic voltammetry or chronoamperometry have proven useful for characterizing their redox properties. These techniques have also been used to study the redox behavior of technetium complexes with potential nuclear medicine use as myocardial imaging agents. The application of ${ }^{99 \mathrm{~m}} \mathrm{Tc}$ in thiamazole solutions under in vitro conditions caused a decrease in peak current in the reduction region of the cyclic voltammogram, which is in line with the work of Kara et al., who examined the electrochemical modification of DNA with radioactive iodine and ${ }^{99 \mathrm{~m}} \mathrm{Tc}$-pertechnetate [30].

Also, the reduction in the activity of radiopharmaceuticals with time influences the kinetics of the formation of free radicals that are responsible for cell damage and the occurrence of hyperthyroidism. Subsequent reoxidation of the $\mathrm{Tc}(\mathrm{IV})$ oxide film to $\mathrm{Tc}(\mathrm{VII})$ leads to the reformation of pertechnetate and/or suspected formation of technetium oxychloro species on the carbon electrode surface [31]. Russell, in his research, found that cathodic reduction of the pertechnetate wave starts at $-0.8 \mathrm{~V}$ on the cathodic sweep and a stripping peak occurs at $-0.1 \mathrm{~V}$ on the anodic sweep. The reduction in wave corresponds to the reduction of pertechnetate and the stripping peak to the oxidation of an insoluble technetium species deposited on the electrode surface, possibly $\mathrm{TcO}_{2}$ [32].

During electrochemical measurement, the transfer of electrons from the surface of the electrode to the drug solution was followed by diffusion and the formation of oxidized and/or reduced states depending on the applied potential. The application of appropriate radiopharmaceuticals is required in thyroid cancer, which we proved by using an in vitro electrochemical method. The values of the reduction potentials decreased with increasing concentration of thiamazole, which also indicates a decrease in the degree of cell damage in the body and better control of hyperthyroidism.

\section{CONCLUSIONS}

Radionuclides, whether applied randomly or intentionally (during diagnosis), may cause different effects, both on the biological organism and on the drugs used for therapeutic purposes. These effects are most commonly manifested as the formation of free radicals breaking bonds within molecules in the body, causing the emergence of new chemical species, or forming new bonds with body molecules. 
Based on the results presented in this work, it can be concluded that the rate of the observed chemical transformations of thiamazole in in vitro conditions in the presence of the ${ }^{99 \mathrm{~m}} \mathrm{Tc}$ solution is lower, which indicates its inhibitory properties and, consequently, the prevention of the formation of free radicals. Also, activity decreased with the time of application of the ${ }^{99 \mathrm{~m}} \mathrm{Tc}$ solution, which is very important when monitoring the progression of thyroid cancer or preventing the onset of hyperthyroidism.

\section{REFERENCES}

[1] I. Villanueva, C. J. Alva-Sánchez, J. Pacheco-Rosado, The role of thyroid hormones as inductors of oxidative stress and neurodegeneration, Oxid. Med. Cell. Longev., 2013, 1-15 (2013).

DOI: https://doi.org/10.1155/2013/218145

[2] B. A. Freeman, J. D. Crapo, Biology of disease: free radicals and tissue injury, Lab. Invest., 47 (5), 412-426 (1982). PMID: 6290784.

https://pubmed.ncbi.nlm.nih.gov/6290784/

[3] A. Mancini, C. D. Segni, S. Raimondo, G. Olivieri, A. Silvestrini, E. Meucci, D. Currò, Thyroid hormones, oxidative stress and inflammation, Mediators of Inflammation, 2016, 1-5 (2016).

DOI: https://doi.org/10.1155/2016/6757154

[4] N. Stathatos, G. H. Daniel, Autoimmune thyroid disease, Curr Opin Rheumatol., 24, 70-75 (2012). DOI: https://doi.org/10.1097/BOR.0b013e32834ddb27

[5] J. Huo, Q. Li, Determination of thiamazole in pharmaceutical samples by phosphorus molybdenum blue spectrophotometry, Spectrochim Acta A Mol. Biomol. Spectrosc., 87, 293-297 (2012).

DOI: https://doi.org/10.1016/j.saa.2011.11.056

[6] P. V. Harper, G. Andros, K. Lathorp, Preliminary observations on the use of six-hour ${ }^{99 \mathrm{~m}} \mathrm{Tc}$ as a tracer in biology and medicine, Argon. Cance. Research Hospital., 18, 176-188 (1962).

DOI:https://digital.library.unt.edu/ark:/67531/metadc102 9367/m2/1/high_res_d/4702168.pdf

[7] R. Mikolajczak, M. Kameswaran, Yttrium-90 and Rhenium188 Radiopharmaceuticals for Radionuclide Therapy. International Atomic Energy Agency, Vienna, Austria, 2015. (https://www-pub.iaea.org/MTCD/Publications/PDF/ Pub1662web-89688003.pdf)

[8] S. Vellabhajosula, Molecular Imaging: Radiopharmaceuticals for PET and SPECT, Springer, New York, 2009. DOI: https://doi.org/10.1007/978-3-540-76735-0

[9] M. Welch, C. S. Redvanly, Handbook of Radiopharmaceuticals: Radiochemistry and Applications, John Wiley \& Sons, London, 2003. (ISBN: 978-0-471-49560-4). DOI: https://doi.org/ DOI:10.1002/0470846380

[10] P. N. Serrano, Electrochemistry of technetium analogs rhenium and molybdenum in room temperature ionic liquid, UNLV Theses, Dissertations, Professional Papers, and Capstones, 2011.

DOI: http://dx.doi.org/10.34917/2817878
[11] C. D. Ramos, D. E. Z. Wittmann, E. C. Sá de Camargo Etchebehere, Thyroid uptake and scintigraphy using ${ }^{99 \mathrm{~m} T c}$ pertechnetate: standardization in normal individuals, Sao Paulo Med J/Rev Paul Med., 120 (2), 45-48 (2002). DOI: http://dx.doi.org/10.1590/S1516-31802002000200004

[12] G. Gopu, P. Manisankar, B. Muralidharan, V. Chinnapiyan, Stripping voltammetric determination of analgetics in their pharmaceuticals using nano-riboflavin-modified glassy carbon electrode, Int. J. Electrochem, 1 (2011). DOI: https://doi.org/10.4061/2011/269452

[13] C. Engin, S. Yilmaz, G. Saglikogluet, S. Yagmur, M. Sadikoglu, Electroanalytical investigation of paracetamol on glassy carbon electrode by voltammetry, Int. J. Electrochemical. Sci., 1917-1918 (2015). DOI:http://www.electrochemsci.org/papers/vol10/1002019 16.pdf

[14] A. A. El-Shanawany, S. M. El-Adl, D. S. El Haleem, Electrochemical characterization and determination of the anticancer drug flutamide, Annalen der chemischen Forschung. 2, 29-40 (2014). (ISSN 2321-1725 (E). http://aocsr.com/index.php/ct-menu-item-12/ct-menuitem-13.html)

[15] H. M. Elqudaby, G. M. Gehad, G. M. G. El Din, Electrochemical behaviour of trimebutine at activated glassy carbon electrode and its direct determination in urine and pharmaceutics by square wave and differential pulse voltammetry, International Journal of Electrochemical Science, 9, 856-857 (2014). http://www.electrochemsci.org/papers/vol9/90200856.pdf

[16] B. Muralidharan, G. Gopu, C. Vedhi, P. Manisankar, Voltammetric determination of analgetics using a montmorillonite modified electrode, Applied Clay Sci., 206-207 (2007).

DOI: https://doi.org/10.1016/j.clay.2007.11.005

[17] M. H. Sanad, Novel radiochemical and biological characterization od ${ }^{99 \mathrm{~m}} \mathrm{Tc}$-histamine as a model for brain imaging, J. Anal. Sci. and Tech., 1-2 (2014).

https://jast-journal.springeropen.com/articles/10.1186/ s40543-014-0023-4

[18] P. Chen, R. L. McCreery, Control of electron transfer kinetics at glassy carbon electrodes by specific surface modification, Anal. Chem., 68, 3958-3865 (1996). DOI: https://doi.org/10.1021/ac960492r

[19] X. Xi, L. Ming, J. Liu, Electrochemical determination of thiamazole at a multi-wall carbon nanotube modified glassy carbon electrode, Journal of Applied Electrochemistry, 40 (8), 1449-1454 (2010). DOI: https://doi.org/10.1007/s10800-010-0122-x

[20] R. W. Murray, Chemically modified electrodes. In: Electroanalytical Chemistry, A. J. Bard (ed.), Marcel Dekker, New York, 1984, p. 191. (https://pubmed.ncbi.nlm.nih.gov)

[21] R. W. Murray, Introduction to the chemistry of molecularly designed electrodes. In: R. W. Murray (ed.), Molecular Design of Electrode Surfaces, Techniques of Chemistry Series. Wiley-Interscience, New York, 1992, (https://lib.ugent.be/catalog/rug01:000267053)

[22] A. J. Bard, L. R. Faulkner, Electrochemical Methods, 2nd ed., Wiley, New York, 2001.

(https://www.wiley.com/enir/Electrochemical+Methods: +Fundamentals+and+Applications, +2nd+Edition-p9780471043720) 
[23] S. Pinzanti, G. Papeschi, E. LaPorta, Potentiometric titration of thiols, cationic surfactants and halides using a solid-state silver-silver sulphide electrode, J. Pharm. Biomed. Anal., 1, 47-53 (1983).

DOI: https://doi.org/10.1016/0731-7085(83)80007-7

[24] S. Shahrokhian, M. Ghalkhani, Voltammetric determination of methimazole using a carbon paste electrode modified with a Schiff base complex of cobalt, Electroanalysis, 20 (10), 1061-1066 (2008).

DOI: https://doi.org/10.1002/elan.200704149

[25] F. Jalali, Z. Hatami, Fast electrocatalytic determination of methimazole at an activated glassy carbon electrode, Iranian Journal of Pharmaceutical Research, 15 (4), 735-741 (2016). PMID: 28243269.

https://europepmc.org/backend/ptpmcrender.fcgi?accid= PMC5316251\&blobtype $=$ pdf

[26] C. S. Cutler, C. J. Smith, G. J. Ehrhardt, T. T. Tyler, S. S. Jurisson, E. Deutsch, Current and potential therapeutic uses of lanthanide radioisotopes, Cancer Biotherapy and Radiopharmaceuticals. 15 (6), 531-545 (2000). DOI: https://doi.org/10.1089/cbr.2000.15.531

[27] F. A. Armstrong, H. A. Heering, J. Hirst, Reaction of complex metalloproteins studied by protein-film voltammetry, Chem. Soc. Rev. 26, 169-179 (1997). DOI: https://doi.org/10.1039/CS9972600169
[28] H. B. Gray, J. R. Winkler, Electron tunneling through proteins, Quart. Rev. Biophys, 36, 341-372 (2003). DOI: https://doi.org/10.1017/s0033583503003913

[29] B. Yilmaz, F. Bayrakceken Nisanci, Electrochemical study of methimazole and its direct determination in pharmaceutical preparations and human serum by square wave and differential pulse voltammetry, Journal of Pharmaceutical Research and Reviews, 1-5 (2017). DOI: https://doi.org/10.28933/jprr-2017-12-0503

[30] P. Kara, K. Dagdeviren, M. Ozsoz, An electrochemical DNA biosensor for the detection of DNA damage caused by radioactive iodine and technetium, Turk $J$ Chem., 31, 243-249 (2007).

[31] B. L. Lawson, S. M. Scheifers, T. C. Pinkerton, The electrochemical reduction of pertechnetate at carbon electrodes in aqueous non-complexing acid media, Journal of Electroanalytical Chemistry and Interfacial Electrochemistry, 177 (1-2), 167-181 (1984). DOI: https://doi.org/10.1016/0022-0728(84)80220-X

[32] C. D. Russell, Carrier electrochemistry of pertechnetate: Application to radiopharmaceutical labelling by controlled potential electrolysis at chemically inert electrodes, The International Journal of Applied Radiation and Isotopes. 28 (3), 241-249 (1977). DOI: https://doi.org/10.1016/0020-708x(77)90069-2 